FIU Law Review

Volume 11

Number 2 Separation of Powers

Article 4

Spring 2016

\title{
The Abuse of Executive Power: Getting Beyond the Streetlight Effect .
}

David E. Bernstein

George Mason University School of Law

Follow this and additional works at: https://ecollections.law.fiu.edu/lawreview

Part of the Constitutional Law Commons

Online ISSN: 2643-7759

\section{Recommended Citation}

David E. Bernstein, The Abuse of Executive Power: Getting Beyond the Streetlight Effect ., 11 FIU L. Rev. 289 (2016).

DOI: https://dx.doi.org/10.25148/lawrev.11.2.4

This Article is brought to you for free and open access by eCollections. It has been accepted for inclusion in FIU Law Review by an authorized editor of eCollections. For more information, please contact lisdavis@fiu.edu. 


\title{
The Abuse of Executive Power: Getting Beyond the Streetlight Effect
}

\author{
David E. Bernstein ${ }^{*}$
}

For decades, scholars concerned about the abuse of presidential (and more generally executive-branch) authority in the domestic sphere and about the watering down of the separation of powers have focused on the scope of Chevron ${ }^{1}$ and other doctrines that demand judicial deference to the executive branch $;{ }^{2}$ the slow, lingering death of the non-delegation doctrine $;{ }^{3}$ and whether standing doctrine unduly inhibits litigants who wish to challenge government actions. ${ }^{4}$

While those are certainly important issues, they all involve doctrines that allow for the judiciary to determine how active it chooses to be in policing the executive branch. A Supreme Court concerned about executive abuses could narrow the scope of Chevron and other deferential doctrines, revive the non-delegation doctrine, loosen standing requirements, or any combination of the three. So while one can argue (and I would argue) that courts have been derelict in their duty to enforce the Constitution's separation of powers, that dereliction, if it is such, has been the conscious decision of Supreme Court Justices. Their choice has been dictated by some combination of the Justices' constitutional ideology and a pragmatic hesitation to tangle with a co-equal branch. If, however, the Justices ever thought it necessary to preserve the integrity of the American constitutional system, Supreme Court doctrine on the issues noted above could easily evolve to accommodate greater judicial supervision of the executive branch.

* George Mason University Foundation Professor, George Mason University School of Law. This article is based in part on material published in DAVID E. BERNSTEIN, LAWLESS: THE OBAMA ADMINISTRATION'S UNPRECEDENTED ASSAULT ON THE CONSTITUTION AND THE RULE OF LAW (2015).

1467 U.S. 837 (1984); see Michael Herz, Chevron is Dead; Long Live Chevron, 115 CoLuM. L. REV. 1867, 1867 (2015) ("Everyone is sick to death of Chevron, and four gazillion other people have written about it, creating a huge pile of scholarship and precious little left to say.").

2 See, e.g., Cynthia Barmore, Auer in Action: Deference after Talk America, 76 OHIO ST. L.J. 813 (2015) (discussing Auer deference).

3 See, e.g., Douglas H. Ginsburg, On Constitutionalism, 2002-2003, CAto SuP. Ct. ReV. 7 (2003); Gary Lawson, Delegation and Original Meaning, 88 VA. L. REV. 327, 351 (2002); John F. Manning, The Nondelegation Doctrine as a Canon of Avoidance, 2000 SUP. CT. REV. 223 (2000); Cass R. Sunstein, Nondelegation Canons, 67 U. CHI. L. REV. 315, 316 (2000).

4 See, e.g., Steven L. Winter, The Metaphor of Standing and the Problem of Self-Governance, 40 StAN. L. REV. 1371, 1395 (1988); Cass R. Sunstein, Standing and the Privatization of Public Law, 88 COLUM. L. REV. 1432, 1434 (1988). 
A more insidious long-term threat to the Constitution's separation of powers is that the executive branch is increasingly undertaking significant but illegal, or at least extra-legal, actions which seem to leave little if any scope for judicial review even if the Supreme Court desired to be far more aggressive about policing executive action. In this Article, I discuss several categories of such actions, while providing examples from the Obama administration. Part I discusses regulations disguised as "guidance," with specific reference to the U.S. Department of Education Office of Civil Rights" "Dear Colleague" letter regarding sexual assault on campus. Part II discusses measures taken during an economic emergency despite an absence of statutory authority for those measures, with specific reference to the government officials surreptitiously making day-to-day decisions for General Motors after the 2008 financial crisis. Finally, Part III discusses the refusal to implement existing law, with specific reference to the Obama administration's illicit, politically motivated delays and postponements in enforcing various provisions of the Affordable Care Act (Obamacare).

\section{REgulations DisGuised as "GUIDANCE”}

The Administrative Procedure Act (APA) requires that federal agencies that wish to issue formal, binding regulations based on the agencies' interpretation of operative statutes go through a formal notice and comment process. ${ }^{5}$ Once that process is complete, a regulation is published in the Federal Register and becomes binding, and can thereafter be reviewed by federal courts. The APA exempts from this process what has come to be known as "guidance," but which the APA calls "interpretative rules [or] general statements of policy."

Issuance of guidance can have benign purposes: Guidance can "help to keep the public informed about what agency staff is thinking and they are a method for administrative bureau chiefs to control their subordinates' behavior." ${ }^{\text {" }}$ But guidance can also be used to in effect impose controversial regulations that agencies prefer not go through the ordinary rulemaking process. Sometimes this preference may be for reasons of convenience or time-sensitivity. ${ }^{8}$ Often, however, its because the agencies know that the rules they wish to promulgate either have a dubious, at best, legal basis, or because they understand that an attempt at formal rulemaking would draw sufficient political opposition to undermine the effort. Regardless, the

55 U.S.C. $\S 553(2015)$.

$6 \quad I d . \S 553(\mathrm{~b})(3)(\mathrm{A})$.

7 John D. Graham \& James W. Broughel, Stealth Regulation: Addressing Agency Evasion of OIRA and the Administrative Procedure Act, 1 HARV. J.L. \& PUB. POL'Y, FEDERALIST ED. 31, 38-39 (2014).

$8 \quad I d$. at 39. 
Supreme Court has recently emphasized agency pronouncements that have "the force and effect of law" cannot be deemed to be "guidance."

The Obama administration has provided us with a perfect example of the use of guidance to evade and subvert the regulatory process. In April 2011, the U.S. Department of Education's Office for Civil Rights (OCR) sent a "Dear Colleague" letter to institutions of higher education around the country. ${ }^{10}$ The letter, citing as authority Title IX of the Education Amendments of 1972's ban on sex discrimination in educational institutions that receive federal funds, and undertaking no meaningful analysis of relevant judicial precedents, demanded that schools change their procedures for investigating sexual assault complaints to comply with detailed and specific OCR dictates. ${ }^{11}$

Despite consistent prescriptive language the Dear Colleague letter describing what schools "should" and "must" do, the OCR disclaimed the notion that it was issuing binding regulations. Rather, footnote 1 of the Dear Colleague letter states, that "this Dear Colleague Letter is a 'significant guidance document' under the Office of Management and Budget's Final Bulletin for Agency Good Guidance Practices."12 OCR, the footnote continues,

issues this and other policy guidance to provide recipients with information to assist them in meeting their obligations, and to provide members of the public with information about their rights, under the civil rights laws and implementing regulations that we enforce. OCR's legal authority is based on those laws and regulations. This letter does not add requirements to applicable law, but provides information and examples to inform recipients about how OCR evaluates whether covered entities are complying with their legal obligations. ${ }^{13}$

Despite this disclaimer, the letter in fact invented new legal requirements for sexual assault investigations, without going through the notice and comment process, and without citing any existing legal authority justifying the imposition of such requirements.

In the letter and in a follow-up 2014 "Questions and Answers" document, ${ }^{14}$ OCR required colleges to lower the level of proof needed to

9 Perez v. Mortgage Bankers Ass'n, 135 S. Ct. 1199. 1204 (2015).

10 Office for Civ. Rts., U.S. Dep’t of Educ., Dear Colleague Letter (Apr. 4, 2011), www2.ed.gov/ about/offices/list/ocr/letters/colleague-201104.pdf [hereinafter Dear Colleague Letter].

11 Id.

12 Id. at n.1.

13 Id.

14 Office for Civ. Rts., U.S. Dep't of Educ., Questions and Answers on Title IX and Sexual Violence (Apr. 2014), www2.ed.gov/about/offices/list/ocr/docs/qa-201404-title-ix.pdf [hereinafter Questions and Answers]. 
find students accused of sexual misconduct guilty. Most universities had long used a "clear and convincing" evidentiary standard for student disciplinary hearings. ${ }^{15}$ OCR announced that universities would be liable for violating Title IX unless they shifted to a more liberal "preponderance" of evidence standard. ${ }^{16}$

OCR also in effect barred schools from providing accused students with a fair disciplinary process. ${ }^{17}$ Though cross-examination is among the core tools by which litigants reveal the truth, and no complainant or plaintiff in a civil or criminal court case could exempt himself from being called as a witness, OCR "strongly discourages" schools from allowing the accused student to cross-examine his accuser, lest it traumatize the accuser. ${ }^{18}$ Nor, apparently, does OCR guidance permit an accused student's representative to cross-examine the accuser. Rather, a school "may choose, instead, to allow the parties to submit questions to a trained third party (e.g., the hearing panel) to ask the questions on their behalf." 19 Even then, "OCR recommends that the third party screen the questions submitted by the parties and only ask those it deems appropriate and relevant to the case." 20

OCR also forbade university disciplinary panels from considering an accusing student's sexual history with anyone other than the accused. ${ }^{21}$ Over the last few decades, almost all American courts have limited the extent to which accused rapists can bring in the sexual past of an alleged victim. $^{22}$ This ensures that rape trials are not in effect also putting the victim on trial. But no jurisdiction has adopted a blanket rule excluding all sexual history evidence not involving the accused, in part because of concerns that such a rule would violate the due process rights of defendants. ${ }^{23}$ Such evidence is occasionally highly relevant to a case, and a blanket rule would deprive the defendant in such cases of a valid defense. ${ }^{24}$

15 James M. Picozzi, Note, University Disciplinary Process: What's Fair, What's Due, and What You Don't Get, 96 YALE L.J. 2132, 2159 n.117 (1987) (citing Nicholas Long, The Standard of Proof in Student Disciplinary Cases, 12 J.C. \& U.L. 71 (1985)) ("Courts, universities, and student defendants all seem to agree that the appropriate standard of proof in student disciplinary cases is one of "clear and convincing' evidence.").

16 Questions and Answers, supra note 14, at 13.

17 Office for Civ. Rts., U.S. Dep't of Educ., Dear Colleague Letter: Sexual Violence: Background, Summary, and Fast Facts (Apr. 4, 2011), http://www2.ed.gov/about/offices/list/ocr/docs/ dcl-factsheet-201104.pdf; see also Questions and Answers, supra note 14.

18 Dear Colleague Letter, supra note 10, at 12.

19 Questions and Answers, supra note 14, at 31.

20 Id.

21 Id.

22 See I. Bennett Capers, Real Women, Real Rape, 60 UCLA L. REV. 826, 858-59 (2013).

23 See, e.g., FED. R. EVID. 412(b)(1)(C) (requiring admission of evidence whose exclusion would violate the defendant's constitutional rights).

24 Imagine, for example, that a video circulates around a college campus showing a male and a female student engaging in what most people would consider a degrading sex act for the woman. The 
OCR also states that a "school should also ensure that hearings are conducted in a manner that does not inflict additional trauma on the complainant," which implies that the school should not start the proceedings with a presumption of innocence, or even a stance of neutrality. ${ }^{25}$ Rather, the reference to "additional trauma" suggests that university officials should assume that any complaint is valid and the accused is guilty as charged.

The result of all this has been what one attorney calls "a shocking lack of 'process,' to say nothing of due process, in the way some universities are handling sexual assault complaints." ${ }^{26}$ So where did OCR get the authority to impose its guidelines? Title IX of the Education Amendments of 1972 is famous for forcing universities to upgrade their women's sports programs to prevent sex discrimination in collegiate athletics, but it goes well beyond that. Courts have held that sexual harassment is a form of sex discrimination, including when one student harasses another. Schools subject to Title IX are responsible for monitoring and preventing harassment. OCR concluded that if Title IX requires universities to combat sexual harassment because it interferes with women's educational opportunities, universities must also punish sexual assault for the same reason. ${ }^{27}$

That's fine as far as it goes - though it raises the issue of whether the reasoning applies to same-sex assault, or assaults by women on men)—but it fails to explain why Title IX requires the specific impositions of the OCR letter. In fact, Title IX likely does not give OCR the authority to dictate the nature of university disciplinary proceedings. No cases suggest that an investigation of an allegation of sexual assault on campus must adhere to anything like the guidelines OCR is imposing on colleges. ${ }^{28}$ The Supreme Court has stated in the context of Title IX that at least when public school officials are sued for allegedly not properly intervening in student-on-

woman then files a complaint with the university, claiming she was sexually assaulted. During the investigation, the complainant claims she would never voluntarily consent to such a degrading act. The accused, however, locates four men willing to testify that they engaged in the exact same act with the accuser, and it was fully consensual. One of them even has his own video of the interaction. Under the OCR guidelines, the student accused of sexual assault would not be allowed to present that evidence.

25 Questions and Answers, supra note 14, at 31.

26 Charles M. Sevilla, Campus Sexual Assault Allegations, Adjudications, and Title IX, THE ChampIOn, Nov. 2015, at 16; see also Elizabeth Bartholet et al., Rethink Harvard's Sexual Harassment Policy, Boston GloBe (Oct. 15, 2014), www.bostonglobe.com/opinion/2014/10/14/rethink-harvardsexual-harassment-policy/HFDDiZN7nU2UwuUuWMnqbM/story.html; Jed Rubenfeld, Mishandling Rape, N.Y.TIMES (Nov. 15,2014),www.nytimes.com/2014/11/16/opinion/sunday/mishandling-rape.html?_r=0.

27 See Dear Colleague Letter, supra note 10.

28 See Hans Bader, Education Department Illegally Ordered Colleges to Reduce Due-Process Safeguards, WASH. EXAMINER (Sept. 21, 2012), www.examiner.com/article/education-departmentillegally-ordered-colleges-to-reduce-due-process-safeguards. 
student harassment "courts should refrain from second guessing the disciplinary decisions made by school administrators." ${ }^{29}$ School officials "must merely respond to known peer harassment in a manner that is not clearly unreasonable." $" 30$ One would presume that the same rationale would apply to claims of sexual assault by a peer at an institution of higher learning.

Even if Title IX does give OCR the power to dictate campus disciplinary rules, OCR needed to go through the normal notice and comment regulatory process before making new regulations, rather than just announcing them through a "Dear Colleague" letter that is subject to neither normal administrative safeguards nor to judicial review. ${ }^{31}$ Of course, OCR would argue that the Dear Colleague letter was mere "guidance" without the force of law, but that is an evasion. In addition to the prescriptive language in the letter noted previously, which suggests that OCR was treating the guidance as having the force of law, we can judge the practical effects of what OCR accomplished by how universities reacted, rather than by whether OCR was officially making new law or not.

Universities around the country scrambled to change their procedures to comport with the guidance set forth in the letter. ${ }^{32}$ Some, feeling pressure from OCR, reopened past investigations that had exonerated the accused. ${ }^{33}$ And what choice did the universities really have? Because OCR did not purport to make a formal, legally binding regulation, there was no way to challenge its guidance in court, and OCR itself, despite the disclaimer in the Dear Colleague letter, was treating the guidance as binding, as it opened multiple investigations of universities for allegedly violating Title IX when dealing with sexual assault claims. Moreover, experience suggested that anything but full and immediate obedience to OCR's agenda in this area would lead to lengthy, costly investigation of university's policy, with the potential penalty of a loss of crucial federal funding, including student

29 Davis v. Monroe Cnty. Bd. of Educ., 526 U.S. 629, 648 (1999).

30 Id. at 649 (emphasis added).

31 Hans Bader, No, OCR's April 4, 2011 Dear Colleague Letter Is Not Entitled to Deference, WASH. EXAMINER (Aug. 17, 2013), www.examiner.com/article/no-ocr-s-april-4-2011-dear-colleagueletter-is-not-entitled-to-deference.

32 Julie Novkov, Equality, Process, and Campus Sexual Assault, 75 MD. L. REv. 590, 595 (2016) (noting that the Dear Colleague Letter "has transformed how higher educational institutions address allegations of sexual assault"). As Novkov explains (without discussing the problematic nature of the explanation), the Dear Colleague letter came in response to concerns from anti-sexual assault activists that Title IX was insufficient to combat sexual violence on campus. In other words, Novkov describes the letter not as an interpretation of Title IX, but as a response to the perceived inadequacies of Title IX. Id.; see also id. at 607-08 ("These changes acknowledge that Title IX does not really address sexual assault and seek to reconfigure it so that it can do so."). Of course, federal agencies do not have the power to make what they see as good policy without having a legal basis for doing so.

33 See David E. Bernstein, Lawless: The Obama Administration's UnPReCEDENTEd ASSAULt ON THE CONSTITUTION AND THE RULE OF LAW, ch. 8 (2015). 
loans. $^{34}$

Indeed, when someone in Congress-Senator Lamar Alexanderfinally got around in 2014 to asking Catherine Lhamon, the Department of Education's Assistant Secretary for the Office for Civil Rights about the letter, she testified that "she expected institutions of higher education to fully comply with OCR's guidance."35 Needless to say, if the government expects "compliance," it is in effect regulating the affected parties, even if it purports to only be issuing "guidance."

Over a year later, Senator Alexander revisited the issue with Department of Education Deputy Assistant Secretary Amy McIntosh:

Senator Alexander: Now Ms. McIntosh, do you believe that we gave Ms. Lhamon the authority to make Title IX guidance binding on 6,000 higher education institutions?

Ms. McIntosh: Let me assure you, I tried to be very clear in my opening statement that guidance that the Department issues does not have the force of law.

Senator Alexander: But this is the assistant secretary of the department, with Title IX, which affects 6,000 institutions, 100,000 public schools. And she apparently hadn't gotten the word. Who's going to tell her?

Ms. McIntosh: So . . .

Senator Alexander: Are you?

Ms. McIntosh: As she knows and as I know, Title IX is the binding law that applies in the cases that you are describing . . .

Senator Alexander: So guidance under Title IX is not binding - is that correct?

Ms. McIntosh: Guidance under Title IX is not binding. Guidance helps the many people who are subject to Title IX understand what they need to do to comply with the law.

Senator Alexander: Right. But who is going to tell Ms. Lhamon this? ${ }^{36}$

34 See Stephen Henrick, A Hostile Environment for Student Defendants: Title IX and Sexual Assault on College Campuses, 40 N. KY. L. REV. 49 (2013) (reviewing past OCR investigations of universities).

35 Joseph Cohn, Department of Education's Overreach Questioned by Senator Lamar Alexander, FIRE (Sept. 30, 2015), www.thefire.org/department-of-educations-overreach-questioned-bysenator-lamar-alexander.

36 Alexander Questions Dept. of Ed. Witness at HSGAC Hearing on Regulatory Guidance, YouTuBE (Sept. 23, 2015), www.youtube.com/watch?v=dIiXuv-Oirw. 
Eight days later, Senator James Lankford followed up with questions to Undersecretary of Education Ted Mitchell:

Senator Lankford: Let me move on to another process-type question, and that is guidance. What is your process on making a decision when you are discussing whether you are going to do a guidance document or regulation? Is there a written out process that you have in place to say if all of these things - or even if one of these things - is true then there needs to be a regulation?

Mr. Mitchell: So we're guided by the OMB bulletins and by our own office of general counsel and the bright line as I believe my colleague Amy McIntosh told you last week is that for us, if there is a-if there is a statement that we want to make, or a statement or an area we believe needs to be investigated and where we need consultation with the field that will result in having the force of law, we believe that at that point we are bound to enter into rulemaking.

Senator Lankford: Clearly the bright line is, if it is binding, then that is a regulation.

Mr. Mitchell: That's right.

Senator Lankford: The challenge that I hear over and over again from institutions of higher education is, they have a tremendous number of guidance documents that are coming to them, and they do not feel the freedom to be able to come back to Education, the Department of Ed, and say this smells a lot like a regulation to me because this is also where a stream of funding comes from. And so, they feel like they have to take it. Where other entities, obviously private businesses, they get a guidance document come down, they file lawsuits, and they challenge, and they push back on it. Institutions of higher education are actually leaning back and saying, I don't feel the freedom to be able to challenge this for fear that we'll also have other things. Now, I'm sure your answer is, they shouldn't be afraid of us; we're their friends. But I would tell you, they are very concerned that they're- not only the way the regulations are coming out, but the frequency of those regulations and the pure cumulative result of that is they're drowning in guidance documents and "Dear Colleague" letters, is actually how they are coming from you, and this sheer number of "Dear Colleague" letters they feel like they can't challenge.

Mr. Mitchell: So let me say that I'm hearing-I hear the same things when I talk to my colleagues in higher education. And in each of those conversations I do try to reiterate what Amy said last week and I will say again. Our guidance does not hold the force of law and our 
recommendations and illustrations of the ways in which we are interpreting the statute and the regulations. So we are happy, in fact, to continue in conversations with institutions of higher education. ${ }^{37}$

So for four years OCR, acting without any plausible claim to be relying on established legal authority, treated its guidance as binding rules that applied to almost every institution of higher learning in the United States and treated those rules as binding. Only after two U.S. senators challenged Department of Education officials did anyone acknowledge publicly that the guidance could legally be deemed only "recommendations" and "illustrations." ${ }^{38}$ Nevertheless, OCR has not sent any follow-up correspondence to universities explaining that its guidance is not binding.

Had OCR instead offered formal regulations through the procedures dictated by the Administrative Procedure Act, universities and others could have (1) challenged the factual underpinning of the new rules for sexual assault cases (the dubious notion that there is a rising epidemic of sexual assault on campuses nationwide) $;^{39}$ (2) argued, probably correctly, that OCR's guidelines are inconsistent with relevant Supreme Court precedent on university obligations regarding peer-on-peer harassment; ${ }^{40}$ and (3) argued that regardless of (1) and (2), OCR was unconstitutionally forcing universities to violate accused students' due process rights. ${ }^{41}$ If OCR had chosen to ignore or reject these arguments, the regulations could then have been challenged in federal court.

37 Quoted in Second Department of Education Official in Eight Days Tells Congress Guidance Is Not Binding, FIRE (Oct. 2, 2015), www.thefire.org/second-department-of-education-official-in-eightdays-tells-congress-guidance-is-not-binding.

38 See Jake New, Guidance or Rule Making?, INSIDE HIGHER ED (Jan. 7, 2016), www.insidehighered.com/news/2016/01/07/senators-challenge-legality-us-guidance-campus-sexual-assault.

39 Sexual assault on campus, as elsewhere in society, is a serious problem, but sex crimes at universities, as elsewhere in society, have declined dramatically over the last twenty years. Figures bandied about by the Obama administration and others to the effect that one in five college women will be sexually assaulted, massively exaggerate the problem's scope. See Rape and Sexual Assault: A Renewed Call to Action, White House Council on Women and Girls (Jan. 2014), www.whitehouse.gov/ sites/default/files/docs/sexual_assault_report_1-21-14.pdf; see also Lynn Langton, Rape And Sexual Assault Among College-Age Females, 1995-2013, U.S. DeP'T OF Just., OfF. OF JuST. Programs, BuREAU OF JUST. STATISTICS (Dec. 11, 2014), www.bjs.gov/content/pub/pdf/rsavcaf9513.pdf; Mark Perry, Before Declaring That There's a "Rape Epidemic" in the U.S., Has Anybody Bothered to Check the Actual Data? Apparently Not, AEI IDEAS (May 17, 2014), www.aei-ideas.org/2014/05/beforedeclaring-that-theres-a-rape-epidemic-in-the-us-has-anybody-bothered-to-check-the-actual-data-apparen tly-not/\#mbl; Cathy Young, The White House Overreaches on Campus Rape, MindING THE CAMPUS (Jan. 23, 2014), www.mindingthecampus.com/2014/01/the_white_house_overreaches_on.

40 See discussion supra notes 28-30.

41 Courts have consistently held that the government acts illegally when it forces a private institution to treat an individual in a way that would be illegal if the government did it directly. E.g., Rattner v. Netburn, 930 F.2d 204 (2d Cir. 1991); Okwedy v. Molinari, 333 F.3d 339 (2d Cir. 2003). 
Instead, we are left with a situation in which the federal government made up rules that apply to almost every college and university in the country, creating a witch-hunt-like atmosphere on many campuses, ${ }^{42}$ with only the barest thread of legal authority to back it up.

\section{EMERGENCY ECONOMIC MEASURES WITH NO STATUTORY AUTHORITY}

The Supreme Court established in Youngstown Sheet \& Tube Co. $v$. Sawyer $^{43}$ (the Steel Seizure Case) that economic emergency, even in a wartime context, does not give the President authority to go act beyond statutory limits. Presidential power is especially constrained when Congress has explicitly declined to give the President the authority he seeks to exercise. ${ }^{44}$ Nevertheless, when economic emergency struck in fall 2008 , the George W. Bush administration ignored statutory limits and the expressed will of Congress and chose to exercise authority that Congress had explicitly denied it. The Obama administration, rather than rolling back this improper exercise of executive power, instead expanded it. The end result was that the federal government ran the day-to-day activities of a major U.S. corporation, General Motors (GM), without any legal authority for doing so.

The Bush administration, with the acquiescence of Congress, established the Troubled Asset Relief Program, or TARP, at the height of the 2008 financial crisis. ${ }^{45}$ TARP authorized the Secretary of the U.S. Treasury "to purchase ... troubled assets from any financial institution, on such terms and conditions as are determined by the Secretary." December 2008, the Bush administration asked Congress for money to bail out Chrysler and GM. The House went along, ${ }^{47}$ but the Senate refused. ${ }^{48}$

In a foreshadowing of Obama administration rhetoric, the Bush administration argued that Congress's refusal to rubber-stamp the President's proposal justified what amounted to unilateral, illegal action by the President. Bush took $\$ 17$ billion out of the $\$ 700$ billion TARP fund to lend to the car companies, even though the fund was only supposed to be

42 See BERNSTEIN, supra note 33, at ch. 8.

43343 U.S. 579 (1952).

44 Id. (Jackson, J., concurring). Though not the opinion for the Court's majority, Justice Jackson's opinion in the long-run has had the most influence.

45 Troubled Asset Relief Program, 12 U.S.C. §§ 5211-41, 5251-53, 5261 (2015).

46 Id. § 5211(a)(1); see also Todd Zywicki, The Auto Bailout and the Rule of Law, 7 NAT'L AFFAIRS 66 (Spring 2011), www.nationalaffairs.com/doclib/20110317_Zywicki.pdf.

47 See Brent J. Horton, The TARP Bailout of GM: A Legal Historical and Literary Critique, 14 TEX. REV. L. \& POL. 216 (2010).

48 David M. Herszenhorn, Bill Vlasic \& Carl Hulse, Senate Abandons Auto Bailout Bid After G.O.P Balks, N.Y. TIMES, Dec. 12, 2008, at A1. 
used for "financial institutions." $"$ A White House spokesman justified this presidential power-grab by explaining, "Congress lost its opportunity to be a partner because they couldn't get their job done." ${ }^{, 50}$

The government then gave GM and Chrysler ninety days to come up with viable turnaround plans. ${ }^{51}$ By the time the deadline arrived, the Obama administration was in office and neither company had made significant progress. ${ }^{52}$ Obama's underlings ordered Chrysler to merge with Italian automaker Fiat. ${ }^{53}$ Steven Rattner, Obama's "car czar," meanwhile ordered GM CEO Rick Wagoner to resign. Given GM's dependence on TARP money, Wagoner had no choice. So an unelected government bureaucratone not even confirmed by the Senate, even though he pretty clearly qualified as a "principal officer" for constitutional purposes - fired the CEO of a major American company. ${ }^{54}$ The Obama administration meanwhile more than tripled the amount of TARP funds available to GM, without Congressional approval. ${ }^{55}$

Rattner also forced out GM's acting chairman and personally recruited its new chairman. ${ }^{56}$ Rattner and his automobile industry task force made all major business decisions for GM, including which brands to keep and which dealerships it should shed and how quickly it should shed them. ${ }^{57}$ For public consumption, the task force pretended that GM was acting autonomously. Rattner later complained that "as we drafted press statements and fact sheets, I would constantly force myself to write that 'GM has done such and such.' Just once I would have liked to write 'we' instead." 58

Needless to say, a law that provided for the bailout of "financial institutions," however broadly construed, did not give the government the power to make day-to-day business decisions for GM. Rattner not only did not care, he reveled in the lawlessness. The auto industry rescue, he wrote, "succeeded in no small part because we did not have to deal with Congress." 59 If he had not been able to act unilaterally, he added, "we

4912 U.S.C. $\$ 5211(\mathrm{a})(1)$.

50 Gene Healy, The Cult of the PREsidency 304 (2009).

51 Todd Zywicki, The Auto Bailout and the Rule of Law, 7 NAT'L AFFAIRS 66, 74-76 (Spring 2011), www.nationalaffairs.com/doclib/20110317_Zywicki.pdf.

$52 \quad I d$.

53 Id.

54 Id.

55 Id.

56 Id.

57 Id.

58 STEVEN RATTNER, OVERHAUL: AN INSIDER'S ACCOUNT OF THE OBAMA ADMINISTRATION'S EMERGENCY RESCUE OF THE AUTO INDUSTRY 210 (2011).

59 Id. at 187. 
would have been subject to endless congressional posturing, deliberating, bickering, and micromanagement, in the midst of which one or more of the troubled companies under our care would have gone bankrupt." ${ }^{60}$ Either that, or the Obama administration could have followed the law and cooperated and compromised with Congress. Given that Congress had a huge Democratic majority inclined to go along with the administration's initiatives, the Obama administration could hardly blame potential partisan obstructionism for its failure to respect the separation of powers.

\section{REFUSAL TO IMPLEMENT THE LAW}

The Obama administration has faced persistent criticism for allegedly picking and choosing which laws it chooses to enforce. Critics have claimed that President Obama has been derelict in his duty to enforce the work requirements of the 1996 welfare reform law, ${ }^{61}$ has illegitimately ordered U.S. attorneys to not enforce the federal ban on marijuana in states where it is legal, and, most famously, has illicitly ordered federal officials not to enforce immigration law. ${ }^{62}$ The legality of President Obama's executive order granting de facto (albeit temporary) legal status to millions of undocumented residents of the United States is currently pending before the Supreme Court. ${ }^{63}$ In a sign that some Justices are concerned that the President has been derelict in his duty to enforce the law, the Court sua sponte added to its cert grant the issue of whether the President's order violates the "Take Care Clause" of the Constitution, a clause that until now the Court has not deemed justiciable as a limit on executive discretion. ${ }^{64}$

With regard to immigration law, the Obama administration has at least a plausible argument that given limited enforcement resources, the President is acting within his discretion by exempting certain classes of undocumented residents from deportation, and that such exemption entitles the adult immigrants in question to receive work permits. ${ }^{65}$ Much more

$60 I d$.

61 See, e.g., Robert Rector, How Obama Has Gutted Welfare Reform, WASH. Post (Sept. 6, 2012), www.washingtonpost.com/opinions/how-obama-has-gutted-welfore-reform/2012/09/06/885b009 2-f835-11e1-8b93-c4f4ab1c8d13_story.html.

62 See Josh Blackman, The Constitutionality of DAPA Part I: Congressional Acquiescence to Deferred Action, 103 GEO. L.J. ONLINE 96 (2015), https://judiciary.house.gov/wp-content/uploads/2016/ 03/Blackman-Supplemental-4.pdf; Josh Blackman, The Constitutionality of DAPA Part II: Faithfully Executing the Law, 19 TEX. REV. L. \& POL. 213, 219 (2015).

63 United States v. Texas, no. 15-674 (pending).

64 See David Bernstein, Supreme Court Bombshell: Does Obama's Immigration Guidance Violate the Take Care Clause?, WASH. POST (Jan. 19, 2016), www.washingtonpost.com/news/volokhconspiracy/wp/2016/01/19/supreme-court-bombshell-does-obamas-immigration-guidance-violate-the-ta ke-care-clause.

65 See Memorandum from the Office of Legal Counsel to the Sec'y of Homeland Sec. and the Counsel to the President 10 (Nov. 19, 2014), www.justice.gov/sites/default/files/olc/opinions/ 
troubling is the administration's refusal to enforce statutory compliance deadlines mandated by the Affordable Care Act, supposedly President Obama's own signature legislative accomplishment. Not only does the administration not have a plausible legal argument for its (in)actions, it has not even attempted to provide any. ${ }^{66}$

Many of these (in)actions were undertaken for transparently political reasons. ${ }^{67}$ For example, Obamacare requires most employers with more than fifty employees to provide an approved insurance plan to their workers by January 1, 2014, or pay a fine per uninsured employee. By 2013, it became apparent that many smaller companies were planning to abandon whatever insurance coverage they had previously provided employees, pay the relatively small fine, and dump their employees onto the Obamacare exchanges, where many of them would qualify for federal subsidies.

To avoid this pending political disaster, on July 2, 2013, the Obama administration announced in a Treasury Department blog post, ${ }^{68}$ that for employers with between fifty and ninety-nine employees the insurance mandate would be postponed until 2015 — not coincidentally, after the 2014 midterm elections. Meanwhile, the administration issued rules with absolutely no legal authority to do so requiring any employer who took advantage of the delay to not subsequently reduce or eliminate health insurance and throw its employees on to the exchanges. In March 2014, the administration delayed full implementation of the employer mandate until $2016 .{ }^{69}$

Similarly, the President's "if you like your plan, you can keep it" lie ${ }^{70}$ became a massive political headache for the Democrats in the fall of 2013. Many individuals and businesses who had insured themselves outside of

attachments/2014/11/20/2014-11-19-auth-prioritize-removal.pdf.

66 Nicholas Bagley, Legal Limits and the Implementation of the Affordable Care Act, 164 U. PA. L. REV. (forthcoming 2016), http://papers.ssrn.com/sol3/papers.cfm?abstract_id=2721391; see also Jonathan H. Adler, The Ad Hoc Implementation and Enforcement of Health Care Reform, in LIBERTY'S Nemesis: The UnChecked ExPAnsion of The StATE 13 (Dean Reuter \& John Yoo eds., 2016).

67 This has been an Obama administration modus operandi in a variety of contexts. See Josh Blackman, The Constitutionality of DAPA Part II: Faithfully Executing the Law, 19 TEX. REV. L. \& PoL. 213 (2015); Juliet Eilperin, White House Delayed Enacting Rules Ahead of 2012 Election to Avoid Controversy, WASH. POST (Dec. 14, 2013), www.washingtonpost.com/politics/white-house-delayedenacting-rules-ahead-of-2012-election-to-avoid-controversy/2013/12/14/7885a494-561a-11e3-ba82-16e d03681809_story.html.

68 Mark J. Mazur, Continuing to Implement the ACA in a Careful, Thoughtful Manner, TREAS. BLOG (July 2, 2013), www.treasury.gov/connect/blog/Pages/Continuing-to-Implement-the-ACA-in-aCareful-Thoughtful-Manner-.aspx.

69 Shared Responsibility for Employers Regarding Health Coverage, 79 Fed. Reg. 8544, 8574 (2014).

70 Angie Drobnic Holan, Lie of the Year: "If You Like Your Health Care Plan, You Can Keep It”, POLITIFACT (Dec. 12, 2013), www.politifact.com/truth-o-meter/article/2013/dec/12/lie-year-if-youlike-your-health-care-plan-keep-it. 
group plans received cancellation notices from their insurance company because their plans did not meet "minimum essential coverage" requirements under Obamacare. On November 14, 2013, the Obama administration issued guidance encouraging state insurance commissioners to allow existing non-Obamacare compliant plans that were in effect on October 1, 2013, to continue through October 1, 2014. ${ }^{71}$ Remarkably, the Obama administration was asking insurance commissioners to disobey federal law. In December, President Obama announced that the federal government would not enforce the individual mandate in 2014 against people whose insurance policies were canceled due to Obamacare. ${ }^{72}$ On March 5, 2014, the administration asked state insurance commissioners not to enforce Obamacare rules that would require existing plans to fold until October 1, 2016 $6^{73}$-again not surprisingly, well after the 2014 midterm elections. Nothing in the statute gave the President the authority to waive the relevant mandatory deadlines.

South Texas College of Law professor Josh Blackman aptly calls the administration's unilateral announcements of changes to Obamacare "government by blog post," a completely unconstitutional way of governing. ${ }^{74}$ Obama preferred governing this way even when Republicans offered to work with him. Before Obama announced that he would ignore the law and allow the grandfathering of otherwise unlawful health care plans, Republicans proposed a bill that would have grandfathered existing plans. The President announced he would veto any such bill. ${ }^{75}$

Professor Nicholas Bagley, a supporter of Obamacare, acknowledges not just that the Obama administration has been unlawful, but that the administration has not even tried to publicly defend its lawfulness:

The Obama administration appears to justify the delays as routine exercises of the executive branch's traditional authority to choose when, where, and under what circumstances to enforce statutes. (I say "appears" since the administration has not, with one exception discussed below, offered a thorough-going public defense of the

71 Letter from Gary Cohen, Dir., Ctr. for Consumer Info. \& Ins. Oversight, U.S. Dep’t of Health \& Human Servs., to State Ins. Comm'rs (Nov. 14, 2013), www.cms.gov/cciio/resources/letters/ downloads/commissioner-letter-11-14-2013.pdf.

72 Ezra Klein, The Individual Mandate No Longer Applies to People Whose Plans Were Canceled, WASH. POST (Dec. 19 2013), www.washingtonpost.com/news/wonk/wp/2013/12/19/theobama-administration-just-delayed-the-individual-mandate-for-people-whose-plans-have-been-canceled.

73 See U.S. Dep't of Health \& Human Servs. (HHS), HHS 2015 Health Policy Standards Fact Sheet (Mar. 5, 2014), www.cms.gov/Newsroom/MediaReleaseDatabase/Fact-sheets/2014-Fact-sheetsitems/2014-03-05-2.html.

74 Josh Blackman, Obamacare and Government by Blog Post, LiBERTyLAw (Mar. 24, 2014), www.libertylawsite.org/2014/03/10/obamacare-and-government-by-blog-post.

75 Justin Sink, White House Threatens Veto of Upton Bill, THE HiLl (Nov. 14, 2013), http:// thehill.com/homenews/administration/190365-white-house-threatens-veto-of-upton-bill. 
delays.)... .

This defense, however, runs counter to legal conventions governing the president's duty to "take Care that the Laws be faithfully executed." Most notably, the administrative delays are not the sorts of "discretionary judgment[s] concerning the allocation of enforcement resources" that, according to Heckler, lie at the heart of the nonenforcement power. The delays are instead bald efforts to avoid unwanted consequences associated with full implementation of the $\mathrm{ACA}^{76}$

Bagley argues that one should not consider the Obama administration to more generally be lawless in its implementation of Obamacare, because the administration has enforced many other provisions that it would have preferred to ignore. ${ }^{77} \mathrm{I}$ am inclined, however, to agree with Professor Jonathan Adler, who rejoins, "where Bagley finds admirable restraint, I suspect calculation. It seems to me the administration has strayed from the ACA's text law when and where it thinks it's difficult for critics to obtain judicial review." 78

\section{CONCLUSION}

This article has reviewed three types of executive branch misbehavior that is difficult or impossible to constrain via judicial review: informally regulating through "guidance" rather than promulgating formal regulations through the notice-and-comment process; ignoring statutory limits and congressional objections in exercising spending and regulatory authority in an economic emergency; and delaying the implementation of duly-enacted legislation for political reasons. This article provided one prominent Obama administration example for each of these.

The article could also have discussed abuses attendant to "sue and settle," which occurs when an agency, frustrated that Congress or the courts are blocking its preferred policies, implicitly colludes with outside groups to settle litigation against the agency on terms that require the agency to do what Congress or the courts previously prohibited. The U.S. Chamber of Commerce estimates that from 2009 to 2012, seventy lawsuits were settled under circumstances such that they can be categorized as sue and settle cases. $^{79}$ While in theory judges could refuse to rubber-stamp these

76 Nicholas Bagley, Legal Limits and the Implementation of the Affordable Care Act, 164 U. PA. L. REV. (forthcoming 2016), http://papers.ssrn.com/sol3/papers.cfm?abstract_id=2721391.

77 Id.

78 Jonathan H. Adler, The Illegal Implementation of Obamacare, WASH. PosT (Jan. 27, 2016), www.washingtonpost.com/news/volokh-conspiracy/wp/2016/01/27/the-illegal-implementation-of-obam acare.

79 William L. Kovacs, Keith W. Holman \& Jonathan A. Jackson, A Report on Sue and Settle: 
settlements, in practice, Article III judges have no coherent mechanism of distinguishing between "sue and settle" settlements and legitimate settlements of adversarial litigation.

The Obama administration also abused executive power in a manner not conducive to judicial oversight when the President undermined an ongoing Justice Department investigation of illegal political discrimination by the IRS by announcing publicly in the middle of the investigation that no intentional wrongdoing occurred. ${ }^{80}$ In another troubling instance, the Justice Department, breaking a longstanding norm that it will defend in court any duly enacted federal law that has a plausible legal defense, refused to defend the Defense of Marriage Act for transparently political reasons. ${ }^{81}$

None of these abuses of executive authority and discretion are easily subject to meaningful judicial oversight. Administrative law professors will undoubtedly keep churning out articles on Chevron and other doctrinal standbys because of the Streetlight Effect. ${ }^{82}$ But to the extent academics are

Regulating Behind Closed Doors, U.S. CHAMBER OF COMMERCE (May 2013), www.uschamber.com/ sites/default/files/documents/files/SUEANDSETTLEREPORT-Final.pdf.

80 While a criminal investigation was still ongoing, President Obama falsely declared that the scandal was the result of "bone-headed decisions" out of a local office and that there is "not even a smidgen [of evidence] of corruption" in the scandal. "Not Even a Smidgen of Corruption": Obama Downplays IRS, Other Scandals, FoxNEws.COM (Feb. 3, 2014), www.foxnews.com/politics/2014/02/ 03/not-even-smidgen-corruption-obama-downplays-irs-other-scandals.

81 For decades, attorneys general of the United States have taken the position that regardless of their administration's own view of a law, "they will not call into question the constitutionality of any federal statute unless the law is so patently unconstitutional that no defense of it could mounted in good conscience." Peter M. Shane, Madison's Nightmare: How Executive Power Threatens AMERICAN DEMOCRACY 127 (2009). Yet with a tight 2012 reelection battle pending, and gay rights groups clamoring for the administration, which had still not announced its support for same-sex marriage, to show some good will, the administration refused to defend the Defense of Marriage Act (DOMA) before the Supreme Court. Attorney General Holder argued that the Justice Department in good conscience could not defend DOMA because there were no legitimate arguments to be made for its constitutionality. U.S. Dep't of Just., Statement of the Attorney General on Litigation Involving the Defense of Marriage Act (Feb. 23, 2011), www.justice.gov/opa/pr/statement-attorney-general-litigationinvolving-defense-marriage-act. That was a rather implausible claim, given that the Department of Justice had defended DOMA in court just a year earlier. When the case reached the Supreme Court, with DOMA defended by counsel for the House of Representatives, Justice Kennedy, for the majority, noted that Holder's "failure to defend the constitutionality of an Act of Congress based on a constitutional theory not yet established in judicial decisions has created a procedural dilemma" and warned that such behavior "poses grave challenges to the separation of powers." United States v. Windsor, $133 \mathrm{~S}$. Ct. 2675, 2688 (2013). See also Ed Whelan, DOMA Ruling Did Not "Vindicate" Eric Holder, BENCH MEMOS, NAT'L REV. (Sept. 29, 2014), www.nationalreview.com/bench-memos/389061/doma-rulingdid-not-vindicate-eric-holder-ed-whelan.

82 As described by Wikipedia, the "streetlight effect is a type of observational bias where people only look for whatever they are searching by looking where it is easiest." Streetlight Effect, WIKIPEDIA https://en.wikipedia.org/wiki/Streetlight_effect (last visited Apr. 18, 2016). It comes from the following old joke:

A policeman sees a drunken man searching for something under a streetlight and asks what the drunk has lost. He says he lost his keys and they both look under the streetlight together. After a few minutes, the policeman asks if he is sure he lost them here, and the drunk replies, no, and that 
concerned with abuses of executive authority, we need to look beyond the familiar and obvious and to the novel mechanisms by which President Obama, and undoubtedly future Presidents, seek to undermine Congress and to arrogate power to themselves. 